\title{
Response of soil fauna to simulated nitrogen deposition: A nursery experiment in subtropical China
}

\author{
XU Guo-liang ${ }^{1,2}$, MO Jiang-ming ${ }^{1, *}$, FU Sheng-lei ${ }^{1}$, PER Gundersen ${ }^{3}$, \\ ZHOU Guo-yi ${ }^{1}$, XUE Jing-Hua ${ }^{1}$ \\ 1. Institute of Ecology, South China Botanical Garden, Chinese Academy of Sciences, Guangzhou 510650, China. E-mail: xugl@ scbg.ac.cn \\ 2. Graduate School of the Chinese Academy of Sciences, Beijing 100049, China \\ 3. Danish Center for Forest, Landscape and Planning, KVL, Hoersholm Kongevej 11, DK-2970 Hoersholm Denmark
}

Revised 2 May 2006; revised 16 September 2006; accepted 25 December 2006

\begin{abstract}
We studied the responses of soil fauna to a simulated nitrogen deposition in nursery experimental plots in Subtropical China. Dissolved $\mathrm{NH}_{4} \mathrm{NO}_{3}$ was applied to the soil by spraying twice per month for 16 months, starting in January 2003 with treatments of $0,5,10,15$ and $30 \mathrm{gN} /\left(\mathrm{m}^{2} \cdot \mathrm{a}\right)$. Soil fauna was sampled after $6,9,13$ and 16 months of treatment in three soil depths $(0-5 \mathrm{~cm}, 5-10$ $\mathrm{cm}, 10-15 \mathrm{~cm}$ ). Soil available $\mathrm{N}$ increased in correspondence with the increasing $\mathrm{N}$ treatment, whereas soil $\mathrm{pH}$ decreased. Bacterial and fungal densities were elevated by the $\mathrm{N}$ treatment. Soil fauna increased in the lower nitrogen treatments but decreased in the higher $\mathrm{N}$ treatments, which might indicate that there was a threshold around $10 \mathrm{gN} /\left(\mathrm{m}^{2} \cdot \mathrm{a}\right)$ for the stimulating effects of $\mathrm{N}$ addition. The $\mathrm{N}$ effects were dependent on the soil depth and sampling time. The data also suggested that the effects of the different $\mathrm{N}$ treatments were related to the level of $\mathrm{N}$ saturation, especially the concentration of $\mathrm{NO}_{3}{ }^{-}$in the soil.
\end{abstract}

Key words: soil fauna; $\mathrm{N}$ deposition; response; subtropical China

\section{Introduction}

The emission of biologically available nitrogen has increased globally (Galloway and Cowling, 2002). In industrial Europe and North America, the amount of deposited N now is 20 times higher than before industrialization (Bartnicki and Alcamo, 1989). With the economic development, high $\mathrm{N}$ deposition also occurs in China. For example, the concentration of $\mathrm{NH}_{4}{ }^{+}$in rain is 5-10 times higher than that found in North America (Chou and $\mathrm{Wu}, 1997)$. On average, $38.4 \mathrm{kgN} /\left(\mathrm{hm}^{2} \cdot \mathrm{a}\right)$ is deposited in the Dinghushan area, West Guangdong (Zhou and Yan, 2001). Generally, China has become one of the three major atmospheric $\mathrm{N}$ deposition areas (Europe, America, and China) (Townsend et al., 1996; Xu et al., 2003). Increased $\mathrm{N}$ deposition causes diverse effects on the constitution and functions of forest ecosystems (Fenn et al., 1998), and even leads to degradation of forests (Li et al., 2003).

Most of the deposited $\mathrm{N}$ will eventually end up in the soil. Until now, only few studies on the effects of $\mathrm{N}$ deposition on soil fauna have been performed. From the NITREX project in Europe it was reported that the species richness and biomass of soil Collembola and Oribatid mites responded to $\mathrm{N}$ deposition in a litterbag experiment in July 1993 (Boxman et al., 1998). But

Project supported by the National Natural Science Foundation of China (No. 30670392) and the "100-Talent" Project of the Chinese Academy of Sciences (CAS). *Corresponding author. E-mail: mojm@scib.ac.cn. one study of only two species is not sufficient to assess whole community responses. $\mathrm{N}$ inputs are beneficial for soil fauna in many agricultural fertilization experiments (Rodgers, 1997; Lindberg and Persson, 2004; Nkem et al., 2002; Whalen et al., 1998; Sarathchandra et al., 2001), which provide indirect information about the effects of atmospheric $\mathrm{N}$ deposition on the soil fauna. However, in order to discover more about the effects of atmospheric $\mathrm{N}$ deposition on the soil fauna community, a simulated experiment designed for this purpose is necessary.

Current studies on the effects of $\mathrm{N}$ deposition on soil fauna come from temperate areas. Compared with temperate areas, there is an even more abundant soil fauna community in tropical conditions (Gonzalez and Seastedt, 2001). At the same time, because forest ecosystems in tropical areas are often not $\mathrm{N}$ limited (Pamela et al., 2002), their responses to atmospheric $\mathrm{N}$ deposition could be stronger than in $\mathrm{N}$ limited temperate ecosystems. Thus a hypothesis is suggested that soil fauna in tropical areas may react more negatively to $\mathrm{N}$ deposition than in temperate areas.

We carried out this study in Dinghushan Biosphere Reserve (DHSBR) in subtropical China using a simulated experimental gradient of $\mathrm{N}$ deposition. The objectives were: (1) to study the effects of $\mathrm{N}$ deposition on soil fauna community characteristics; (2) to study the effects of increasing $\mathrm{N}$ deposition on soil fauna abundance and diversity; (3) to identify the mechanisms of $\mathrm{N}$ deposition effects on soil fauna. 


\section{Materials and methods}

\subsection{Site description}

DHSBR is located near Zhaoqing City of southern China, $23^{\circ} 08^{\prime} \mathrm{N}, 112^{\circ} 35^{\prime} \mathrm{E}$. The DHSBR occupies an area of more than $1155 \mathrm{hm}^{2}$. Because it is relatively close to the Pacific Ocean in the east and south, and close to Indian Ocean in the southwest, there are often warm and humid southeast winds and southwest winds in the summer, and often tropical storms including typhoons bring rich rainfall in the summer and fall; the climate belongs to lower subtropical monsoon humid, with solar radiation providing $4655 \mathrm{MJ} /\left(\mathrm{m}^{2} \cdot \mathrm{a}\right)$ and sunshine duration averaging $1433 \mathrm{~h} / \mathrm{a}$. The average temperature is $20.9^{\circ} \mathrm{C}$, and annual average rainfall is $1900 \mathrm{~mm}$ (Xia et al., 1997; Hou et al., 2002). The soils in this area mainly consist of lateritic red-earth, with yellow-earth and mountain shrubby-meadow soil also present; soil pH is 4.2-5.0 (Hou et al., 2002).

\subsection{Experimental design}

The experimental design was a randomized complete block, consisting of five treatments, with three replications (plots) in each case. Soil in the research site was mixed to obtain a uniform mixture before the start of experiment in October 2002 and all weeds were removed during this soil treatment. Fifteen plots of dimensions $4 \mathrm{~m}$ by $5 \mathrm{~m}$ were established and each plot was surrounded by a $1-\mathrm{m}$ wide buffer strip. One-year-old seedlings of three tree species (Schima superba, Castanopsis chinensis, and Cryptocarya concinna) were obtained from a nearby experimental field. A total of 1800 seedlings (600 seedlings per species) were prepared. On October 25, 2002, forty seedlings of each species were transplanted into each plot of the study site. Throughout the experiment, weeds were removed regularly by hand.

Five $\mathrm{N}$ addition treatments (in three replicates) were established: control (without $\mathrm{N}$ added), low $\left(5 \mathrm{gN} /\left(\mathrm{m}^{2} \cdot \mathrm{a}\right)\right.$ ), medium $\left(10 \mathrm{gN} /\left(\mathrm{m}^{2} \cdot \mathrm{a}\right)\right)$, high $\left(15 \mathrm{gN} /\left(\mathrm{m}^{2} \cdot \mathrm{a}\right)\right)$ and double high $\left(30 \mathrm{gN} /\left(\mathrm{m}^{2} \cdot \mathrm{a}\right)\right)$ nitrogen deposition. Fertilizer was weighed, mixed with $10 \mathrm{~L}$ of water, and applied to the plots using a backpack sprayer. $\mathrm{NH}_{4} \mathrm{NO}_{3}$ solution was sprayed by hand onto the soil in the middle and at the end of each month from January 2003 until April 2004. Two passes were made across each plot to ensure an even distribution of fertilizer. The control plots received $10 \mathrm{~L}$ water without $\mathrm{N}$ added.

\subsection{Soil microorganism, fauna and soil sampling}

The upper $10 \mathrm{~cm}$ mineral soils were sampled in November 2003, February 2004 and May 2004. In each plot, five soil cores $(2.8 \mathrm{~cm}$ in diameter) were collected randomly and combined to one composite sample in the field, yielding a sample size of three for each $\mathrm{N}$ treatment. One 10 g subsample was used for soil property analysis and the remaining sample from each composite sample was used to investigate microbial abundance.

We performed soil fauna sampling in July and October 2003, and in February and May 2004 (6, 9, 13 and 16 months after treatment started). In each plot five sampling points were selected by diagonal method and at each point, a soil core was taken by a cylindrical soil corer with an internal diameter of $60 \mathrm{~mm}$ and divided into three depth intervals $(0-5,5-10,10-15 \mathrm{~cm})$. In each plot, the samples were bulked to make one sample per layer, yielding a sample size of three for each $\mathrm{N}$ treatment and for each layer. We took these samples immediately back to the laboratory for fauna analysis.

\subsection{Samples treatment}

Extractable $\mathrm{NH}_{4}{ }^{+}-\mathrm{N}$ was determined colorimetrically by the indophenol blue method and $\mathrm{NO}_{3}{ }^{-}-\mathrm{N}$ was analyzed by copper-cadmium reduction method (Liu et al., 1996). Soil $\mathrm{pH}$ was measured in distilled water suspension using the glass electrode, after shaking for $1 \mathrm{~h}$ at a ratio of $25 \mathrm{ml}$ water to $10 \mathrm{~g}$ mineral soil (Liu et al., 1996). Microbial community abundance was measured by the dilution plate method, with a beef extract and peptone culture medium (2-3 d) for bacteria and MD culture medium (6-7 d) for fungi (Institute of Soil Science, 1985). Soil fauna were collected with dry Tullgren funnels for $6 \mathrm{~h}$ (Liao et al., 1997). We sorted and counted all of the soil fauna using a dissecting microscope and classified them to genera, families or superfamilies except for mites, which were classified to suborder, using key books of soil fauna (Yin, 1998; Zhen and Gui, 1999). These levels of taxonomic identification were regarded as sufficient for characterizing the response patterns of the soil macroinvertebrate community (Kuperman, 1996).

\subsection{Data analysis}

To determine soil fauna community diversity, the following diversity index (DG) (Liao et al., 1997) was used:

$\mathrm{DG}=(g / G) \sum_{i=1}^{g}\left(\left(D_{i} C_{i}\right) /\left(D_{i \max } C\right)\right)$

Where, $g$ is the group number in a single soil fauna community (for example, for one type of $\mathrm{N}$ treatment); $G$ is the summary of all groups; $D_{i}$ is the individuals of $i$ group in a single community; $D_{i \max }$ is the max individuals of $i$ group among the all communities; $C_{i}$ is the frequencies of $i$ group occurring among all of the communities; $C$ is the number of soil fauna communities.

We performed a three-way ANOVA to examine the effects of main factors, $\mathrm{N}$ treatment, sampling date and soil depth, and their interactions on soil fauna abundance of individuals, group richness (the number of taxonomic groups), and DG diversity index. We examined the effects of $\mathrm{N}$ treatment on microbial density and soil parameter responses to $\mathrm{N}$ treatment with one-way ANOVA. An $F$ test was used to identify the effects of main factors and their interactions. Differences among levels of one factor were identified by a Duncan test, and paired sample $t$-test were used to identify the differences between the values of 2004 and values of 2003 for soil fauna density and richness during the sampling period. All tests were considered to be significant at the 0.05 level unless otherwise stated. SPSS 11.5 was used for all analyses. 


\section{Results}

\subsection{Responses of microbial densities and soil properties to $\mathbf{N}$ additions}

Generally, the abundance of soil bacteria and fungi increased significantly with increasing levels of $\mathrm{N}$ addition $(P<0.05$, Table 1). Abundance of bacteria and fungi were significantly lower in control plots $(P<0.05$, Table 1$)$.

Similarly, soil available $\mathrm{N}$, especially soil $\mathrm{NO}_{3}{ }^{-}-\mathrm{N}$, increased with increasing concentration of $\mathrm{N}$ treatment (Table 1). The soil $\mathrm{NO}_{3}{ }^{-}-\mathrm{N}$ was significantly lower in the control plots than in all $\mathrm{N}$ treated plots $(P<0.05)$, with the highest soil $\mathrm{NO}_{3}{ }^{-}-\mathrm{N}$ in the plots treated with $30 \mathrm{~g} \mathrm{~N}$ (Table 1). However, the soil $\mathrm{pH}$ decreased with increasing levels of $\mathrm{N}$ additions and was significantly lower than control plots in $15 \mathrm{~g} \mathrm{~N}$ plots and $30 \mathrm{~g} \mathrm{~N}$ plots $(P<0.05$, Table 1$)$.

\subsection{Effects of sampling date}

Sampling date affected significantly the abundance of individuals, group richness and DG index of soil fauna community (Table $2, P<0.001$ ). Overall, the soil fauna density and richness increased during the sampling period; the values of 2004 were much higher than those of 2003 $(P<0.05$, Fig.1). The interactions between sampling date and $\mathrm{N}$ treatment, and between sampling date and soil depth on soil fauna, were also significant (Table 2).

\subsection{Effects of soil layer}

The vertical distribution of soil fauna was obvious (Table 2, Fig.2), because soil fauna abundance of individuals, group richness and DG index in layer I were significantly higher than in the two deeper soil layers (layer I: 611.67 , 112.71 and 6.88; layer II: 391.45, 87.86 and 3.20; layer III: 288.92, 76.33 and 2.37, respectively) $(P<0.001$, Fig.2). All parameters of soil fauna were in the order from highest to lowest: $\mathrm{I}>\mathrm{II}>\mathrm{III}$ in all $\mathrm{N}$ treated plots except those treated with $30 \mathrm{~g} \mathrm{~N}$ (Fig.2). In the plots treated with $30 \mathrm{~g} \mathrm{~N}$, soil fauna group richness and DG index in layer III (85.36 and 3.13) increased over layer II (77.12 and 2.62), significantly so for group richness $(P<0.05)$ (Fig.2).

\subsection{Effects of $N$ treatments}

The group richness and DG index but not abundance of individuals of soil animals were significantly affected by $\mathrm{N}$ addition $(P<0.05$, Table 2$)$. Generally, in $10 \mathrm{~g} \mathrm{~N}$ plots, the group richness (78.40) was significantly higher than in control (60.49), $15 \mathrm{~g} \mathrm{~N}(67.82)$ and $30 \mathrm{~g} \mathrm{~N}(66.10)$ plots by $29.60 \%, 15.6 \%$ and $18.60 \%$, respectively $(P<0.05)$, and the DG indices were significantly higher in $10 \mathrm{~g} \mathrm{~N}$ plots (3.73) than that in control (2.63) and $30 \mathrm{~g} \mathrm{~N}$ (2.82) plots by $41.38 \%$ and $32.26 \%$, respectively $(P<0.05)$ (Figs.1b and 1c).

The group richness and DG index but not abundance of individuals of soil animals were significantly affected by $\mathrm{N}$ addition $(P<0.05$, Table 2$)$. Generally, in $10 \mathrm{~g} \mathrm{~N}$ plots, the group richness (78.40) was significantly higher than in control (60.49), $15 \mathrm{~g} \mathrm{~N}(67.82)$ and $30 \mathrm{~g} \mathrm{~N}(66.10)$ plots by $29.60 \%, 15.6 \%$ and $18.60 \%$, respectively $(P<0.05)$, and the DG indices were significantly higher in $10 \mathrm{~g} \mathrm{~N}$ plots (3.73) than that in control (2.63) and $30 \mathrm{~g} \mathrm{~N}$ (2.82) plots by $41.38 \%$ and $32.26 \%$, respectively $(P<0.05)$ (Figs.1b and 1c). In general, soil fauna community richness was enhanced in all of the $\mathrm{N}$ treated plots compared with the control plots (Fig.1), in addition, there was significant interaction between $\mathrm{N}$ treatment and sampling date on soil fauna (Table 2).

The differences between $\mathrm{N}$ treated plots and control plots increased with sampling date (Fig.1). For abundance of soil fauna individuals, there was no significant difference between any treatments after 6 months, but the abundance was significantly lower in control (148.83) than in $15 \mathrm{~g} \mathrm{~N}(216.62)$ and $30 \mathrm{~g} \mathrm{~N}$ (212.33) treatments after 9 months $(P<0.05)$; this difference had increased after 16 months $(P<0.05)$ (Fig.1a). Group richness was significantly lower in the controls (36.78) than in $10 \mathrm{~g}$

Table 1 Effects of nitrogen treatments on soil microorganisms and soil properties

\begin{tabular}{|c|c|c|c|c|c|}
\hline & Control & $5 \mathrm{gN} /\left(\mathrm{m}^{2} \cdot \mathrm{a}\right)$ & $10 \mathrm{gN} /\left(\mathrm{m}^{2} \cdot \mathrm{a}\right)$ & $15 \mathrm{gN} /\left(\mathrm{m}^{2} \cdot \mathrm{a}\right)$ & $30 \mathrm{gN} /\left(\mathrm{m}^{2} \cdot \mathrm{a}\right)$ \\
\hline Bacteria $\left(10^{5} / \mathrm{g}\right.$ dry soil $)$ & $261.92(50.20)^{\mathrm{c}}$ & $365.06(87.70)^{\mathrm{b}}$ & $339.96(30.20)^{b}$ & $440.19(69.19)^{\mathrm{a}}$ & $457.56(14.40)^{\mathrm{a}}$ \\
\hline Fungi $\left(10^{4} / \mathrm{g}\right.$ dry soil $)$ & $10.70(0.67)^{\mathrm{d}}$ & $11.79(1.76)^{\mathrm{cd}}$ & $13.50(1.01)^{\mathrm{c}}$ & $16.27(2.19)^{\mathrm{b}}$ & $24.69(1.53)^{\mathrm{a}}$ \\
\hline $\mathrm{NO}_{3}{ }^{-}-\mathrm{N}(\mathrm{mg} / \mathrm{kg})$ & $4.29(1.34)^{\mathrm{c}}$ & $7.00(1.71)^{\mathrm{b}}$ & $8.75(1.02)^{\mathrm{b}}$ & $8.83(2.43)^{\mathrm{b}}$ & $12.92(1.57)^{\mathrm{a}}$ \\
\hline $\mathrm{NH}_{4}{ }^{+}-\mathrm{N}(\mathrm{mg} / \mathrm{kg})$ & $4.93(1.42)^{\mathrm{b}}$ & $3.40(0.43)^{\mathrm{b}}$ & $4.20(0.42)^{\mathrm{b}}$ & $4.93(1.50)^{\mathrm{b}}$ & $6.91(1.25)^{\mathrm{a}}$ \\
\hline $\mathrm{pH}$ & $5.2(0.03)^{\mathrm{a}}$ & $4.9(0.14)^{\mathrm{ab}}$ & $4.9(0.09)^{\mathrm{ab}}$ & $4.8(0.14)^{b}$ & $4.7(0.15)^{b}$ \\
\hline
\end{tabular}

Data are means of three samplings (November 2003, February 2004 and May 2004); data in parenthesis are SE; means followed by different letter within a row differ significantly at $P<0.05$.

Table 2 F -Values of three-way ANOVA

\begin{tabular}{llll}
\hline & Density $F$-value & Group richness $F$-value & DG index $F$-value \\
\hline Sampling date & $98.67^{* * *}$ & $64.31^{* * *}$ & $44.52^{* * *}$ \\
Nitrogen & $0.9^{\text {ns }}$ & $4.73^{* * *}$ & $2.75^{*}$ \\
Soil depth & $44.72^{* * *}$ & $32.62^{* * *}$ & $63.59^{* * *}$ \\
Sampling date $\times$ nitrogen & $1.91^{*}$ & $2.06^{*}$ & $2.42^{* *}$ \\
Sampling date $\times$ soil depth & $20.60^{* * *}$ & $27.94^{* * *}$ & $33.19^{* * *}$ \\
Nitrogen $\times$ soil depth & $0.96^{\mathrm{ns}}$ & $1.51^{\mathrm{ns}}$ & $2.15^{*}$ \\
Sampling date $\times$ nitrogen $\times$ soil depth & $1.22^{\mathrm{ns}}$ & $0.68^{\mathrm{ns}}$ & $1.58^{\mathrm{ns}}$ \\
\hline
\end{tabular}

Nitrogen $\left(0,5,10,15\right.$ and $30\left(\mathrm{gN} /\left(\mathrm{m}^{2} \cdot \mathrm{a}\right)\right)$; soil depth $(0-5,5-10,10-15 \mathrm{~cm})$; and sampling date $(6,9,13,16$ months later $) * * * P<0.001 ; * * P<0.01 ; *$ $P<0.05 ;{ }^{\mathrm{ns}} P>0.05$. 

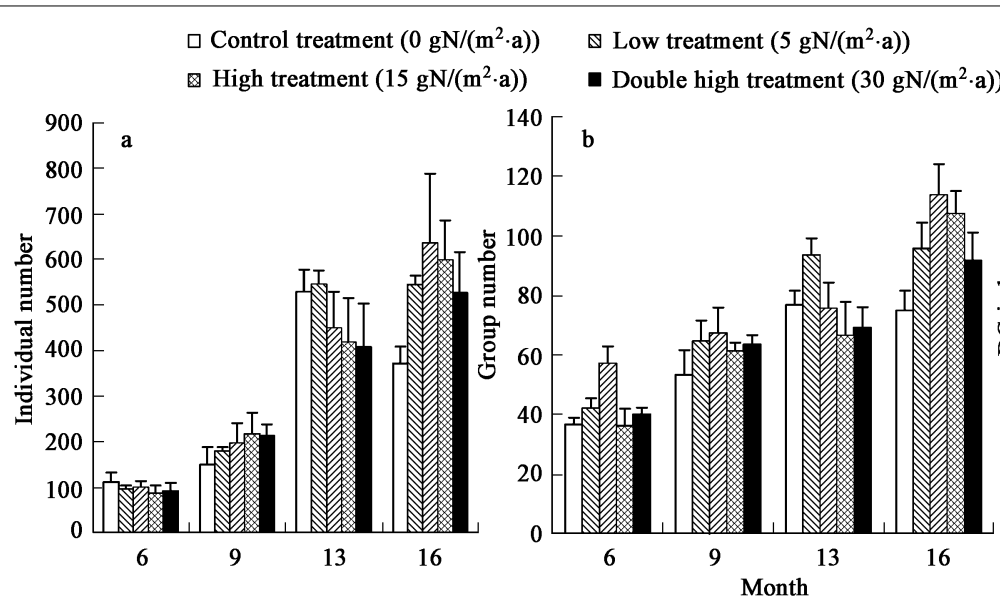

Medium treatment $\left(10 \mathrm{gN} /\left(\mathrm{m}^{2} \cdot \mathrm{a}\right)\right)$

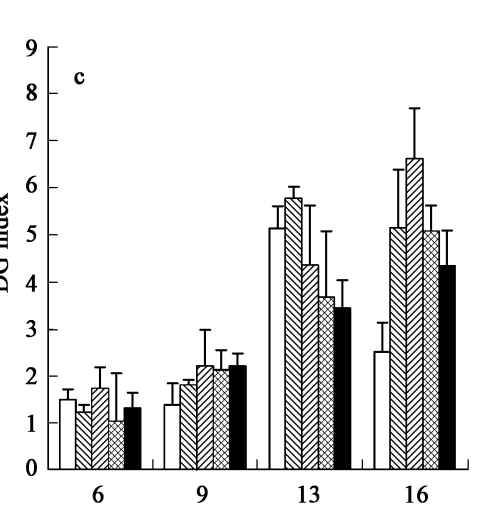

Fig. 1 Effects of nitrogen treatment and sampling date on soil fauna individual number (a), group number (b) and DG index (c). X-axis represents months after the experiment beginning. $P<0.05$.

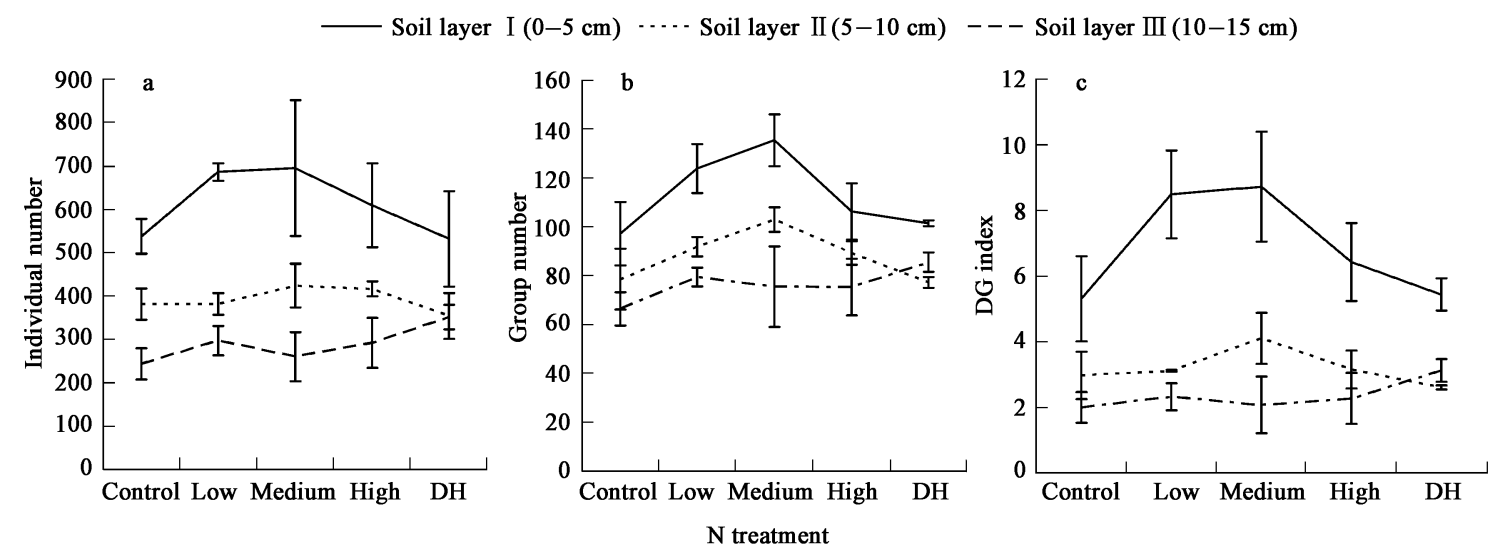

Fig. 2 Effects of nitrogen and soil depth on soil fauna individual number (a), group number (b) and DG index (c). Control: $0 \mathrm{gN} /\left(\mathrm{m}^{2} \cdot \mathrm{a}\right) ; 1$ low: $5 \mathrm{gN} /\left(\mathrm{m}^{2} \cdot \mathrm{a}\right)$; medium: $10 \mathrm{gN} /\left(\mathrm{m}^{2} \cdot \mathrm{a}\right)$; high: $15 \mathrm{gN} /\left(\mathrm{m}^{2} \cdot \mathrm{a}\right)$; $\mathrm{DH}\left(\right.$ double high): $30 \mathrm{gN} /\left(\mathrm{m}^{2} \cdot \mathrm{a}\right)$.

$\mathrm{N}(57.14)$ and $30 \mathrm{~g} \mathrm{~N}(40.13)$ treatments after 6 months $(P<0.05)$, and significantly lower (53.38) than $5 \mathrm{~g} \mathrm{~N}$ (64.67) and $10 \mathrm{~g} \mathrm{~N}$ (67.35) plots after 9 months; again, this difference increased over the 16 months of the study (Fig.1b). After 6 months the community diversity was only significantly lower in control (1.50) than in $10 \mathrm{~g} \mathrm{~N}(1.73)$ plots $(P<0.05)$, but after 9 months and 16 months, the control was significantly lower (1.38 and 2.58) than in $10 \mathrm{~g}$ $\mathrm{N}$ (2.21 and 6.61), $15 \mathrm{~g} \mathrm{~N}$ (2.13 and 5.08) and $30 \mathrm{~g} \mathrm{~N}(2.21$ and 4.33) plots $(P<0.05)$; it was the lowest in control (2.51) than other treatments $(5.15,6.61,5.08$ and 4.33) after 16 months $(P<0.05)$ (Fig.1c). Additionally, from July 2003 to May 2004 (Fig.1), soil fauna community increased from July 2003 to February 2004 and then declined in May 2004 in control plot, but increased constantly over time in the $\mathrm{N}$ treated plots, especially for the individuals under $10 \mathrm{~g} \mathrm{~N}$, $15 \mathrm{~g} \mathrm{~N}$ and $30 \mathrm{~g} \mathrm{~N}$ treatments (Fig.1a), the developments were all significant $(P<0.05)$.

There was also an interaction between $\mathrm{N}$ inputs and soil depth and a threshold of $\mathrm{N}$ treatment across different treatments was visible at soil layer I (Table 2; Fig.2). Two opposite trends occurred with the increased $\mathrm{N}$ inputs (Fig.2). In layer I, soil fauna community increased from control to $10 \mathrm{~g} \mathrm{~N}$ treatment but decreased thereafter; the diversity and group abundance in $10 \mathrm{~g} \mathrm{~N}$ (8.72 and 135.32) and $5 \mathrm{~g} \mathrm{~N}$ (8.49 and 123.65) plots were significantly higher compared with those in control (5.31 and 97.11), $15 \mathrm{~g} \mathrm{~N}$ (6.43 and 106.15), and $30 \mathrm{~g} \mathrm{~N}$ (5.44 and 101.33) plots $(P<0.05)$ (Fig.2). In layer II, soil fauna community also increased from control plots to $10 \mathrm{~g} \mathrm{~N}$ plots and then decreased from $10 \mathrm{~g} \mathrm{~N}$ plots to $30 \mathrm{~g} \mathrm{~N}$ plots, and values from $10 \mathrm{~g} \mathrm{~N}$ plots were also significantly higher than other treatments $(P<0.05)$ (Fig.2). In layer III, soil fauna was relatively scarce in all treatments (Fig.2). However, in the $30 \mathrm{~g} \mathrm{~N}$ treatment, soil fauna group richness and DG index and, in particular, group richness were greater in layer III (85.36 and 3.13) than in layer II (77.12 and 2.62) by the end of the experiment (Figs.2b and 2c).

Soil fauna community in layer I was sensitive to $\mathrm{N}$ deposition for the direct effect; where, soil fauna community obviously increased from control plots to $10 \mathrm{~g} \mathrm{~N}$ plots and then declined, and the highest point or inflexion appeared in $10 \mathrm{~g} \mathrm{~N}$ treatment (Fig.2). Under the most $\mathrm{N}$ treatment, 30 $\mathrm{g} \mathrm{N}$, soil fauna seemed concentrated in deeper soils (Fig.2).

\section{Discussion}

\subsection{Positive effects of $\mathbf{N}$ treatments on soil fauna}

In the present study, soil fauna density in $\mathrm{N}$ treated plots was obviously greater than that in control plots and the difference generally increased over time. The abundance 
of soil bacteria and fungi increased significantly with increasing $\mathrm{N}$ inputs, which might have contributed to the increase of soil fauna because soil microbes are important food resources for soil fauna. Similarly, soil available N increased with increasing $\mathrm{N}$ inputs, which might also have contributed to the increase of soil fauna (Zhang, 1995; Su et al., 1995; Zhang, 2002). Previous studies have reported that when soil available $\mathrm{N}$ increased from 69.8 to 84.7 $\mathrm{mg} / \mathrm{kg}$, soil fauna increased from $5375 \mathrm{~m}^{-2}$ to $11725 \mathrm{~m}^{-2}$ (Huang and Sheng, 1996) and the abundance of Collembola in $\mathrm{N}$ treated plots was twice the abundance of that in control plots (Rodgers, 1997). It has also been reported that soil available $\mathrm{N}$ is the most important factor affecting Acarina and the total number of soil fauna community ( $\mathrm{Su}$ et al., 2001). In addition, the content of soil ammonium is significantly correlated to the biomass of soil Enchytraeids (Sulkava et al., 1996). In fact, nitrogen is one of the major nutrients for organisms, and additional $\mathrm{N}$ inputs to a certain extent are usually beneficial to organisms. Previous studies have reported that the abundance of Enchytraeid in all fertilized plots increased by up to $400 \%$ compared with that in controls (Abrahamsen and Thompson, 1979). In NITREX, Boxman et al. (1998) found that Collembola was more diverse under low ambient $\mathrm{N}$ deposition. Along the acidic Ohio River Valley, the total abundance and the number of decomposers and predators were much higher in a site receiving low doses of N (Kuperman, 1996). These are consistent with our results, with the $\mathrm{N}$ inputs having positive effects on soil fauna density and group richness during the experimental period.

\subsection{Threshold of $\mathbf{N}$ treatments}

Although low and medium doses of $\mathrm{N}$ had great positive effects on soil fauna in this study, higher $\mathrm{N}$ deposition treatments appeared to have some negative effects. Generally soil fauna group richness and diversity were significantly higher in $10 \mathrm{~g} \mathrm{~N}$ plots. In soil layer I, soil fauna increased significantly from the control to the $10 \mathrm{~g} \mathrm{~N}$ treatment and then decreased with increasing $\mathrm{N}$ inputs, and the highest point or inflexion was observed in $10 \mathrm{~g} \mathrm{~N}$ treatment. This indicated that there might be a threshold at around $10 \mathrm{~g} \mathrm{~N}$ treatment in the effects of $\mathrm{N}$ deposition on soil fauna.

Threshold effects of $\mathrm{N}$ deposition have been observed in many studies on plants and microbes. For example, Magill et al. (2000) found that the biomass of all forests increased to different extents with $\mathrm{N}$ deposition additions for nine years compared with control, but woody biomass of pine decreased with $\mathrm{N}$ inputs and woody biomass under the highest $\mathrm{N}$ treatment was significantly lower than the control nine years later (Magill et al., 2000). Although the effect of $\mathrm{N}$ additions at a certain level was positive to soil fauna as described above, the negative effect developed under high level of $\mathrm{N}$ input. Fertilization as high as 12 $\mathrm{gN} /\left(\mathrm{m}^{2} \cdot \mathrm{a}\right)$ in a cotton field decreased the number of soil fauna (Nkem et al., 2002). In a corn field, fertilization $\left(\mathrm{NH}_{4} \mathrm{NO}_{3}, 15 \mathrm{gN} /\left(\mathrm{m}^{2} \cdot \mathrm{a}\right)\right)$ caused significant decreases of earthworm abundance and biomass after 6 years (Whalen et al., 1998). Under high dose $\left(40 \mathrm{gN} /\left(\mathrm{m}^{2} \cdot \mathrm{a}\right)\right)$ treatments, the nematode maturity index decreases drastically
(Sarathchandra et al., 2001). This negative effect of $\mathrm{N}$ deposition can explain our findings, that soil fauna were more abundant in deep soil under the high $\mathrm{N}$ deposition (Fig.2). Perhaps they took refuge there to avoid the high $\mathrm{N}$ concentrations in the upper layers.

The occurrence of a threshold may closely related to soil $\mathrm{N}$ saturation, especially regarding $\mathrm{NO}_{3}{ }^{-}$. During the process of $\mathrm{N}$ deposition, a certain amount of $\mathrm{NO}_{3}{ }^{-}$can be used by forest ecosystem, but excessive $\mathrm{NO}_{3}{ }^{-}$will leach out or accumulate partially in the soil. When fluxes of nitrogen (mineralization and inputs) are equaled to the absorption ability by soil, the ecosystem becomes $\mathrm{N}$ saturated (Xiao, 2001). Excessive nitrogen addition in an $\mathrm{N}$-saturated ecosystem will significantly accelerate soil acidification (Xiao, 2001). It was reported that leaching of base cations, such as $\mathrm{Ca}, \mathrm{Al}$ and $\mathrm{Mn}$ increased with excessive $\mathrm{NO}_{3}{ }^{-}$(Foster et al., 1989; Bergkvist and Folkeson, 1992; Watmough et al., 1999). $\mathrm{Ca}^{2+}$ leaching will further increase the acidification of soil (Foster et al., 1989). The excessive concentration of $\mathrm{NO}_{3}{ }^{-}$may increase the soil acidification and the ratio of $\mathrm{Al}^{3+}$ to $\mathrm{Ca}^{2+}$, which will directly or indirectly damage the ecosystem (Kros et al., 1993). In a conclusion, $\mathrm{NO}_{3}{ }^{-}$inputs might be positive until saturation is reached and negative beyond saturation levels. In the present study, $\mathrm{NO}_{3}{ }^{-}$content in all of $\mathrm{N}$ treated plots was significantly higher than that in control plots, and it was the highest in $30 \mathrm{~g} \mathrm{~N}$ plots among all treatments; and $\mathrm{pH}$ in $30 \mathrm{~g} \mathrm{~N}$ plots decreased compared with that in control plots. This might indicate an $\mathrm{N}$ saturation in soil. The changes in $\mathrm{NO}_{3}{ }^{-}$content and $\mathrm{pH}$ might lead to the responses of soil fauna. The number of individuals, group abundance and diversity in $\mathrm{N}$ treated plots increased consistently compared with that in control plots, but in 30 $\mathrm{g} \mathrm{N}$ plots, soil fauna seemed concentrated into deeper soil layers.

\subsection{DG index}

The Shannon-weaver index $\left(H^{\prime}\right)$ is a widely used diversity index in the study of soil fauna in the past. $H$ ' diversity is suggested to be closely related to even characteristics of the community but not richness $(\mathrm{Fu}$ et al., 2002); and it will reach the largest value if the individual number within every group is equal. Thus, it is adapted to communities with little taxonomic variation (Liao et al., 1997). However, soil fauna groups are extremely diverse in both abundance and biomass. Therefore $H^{\prime}$ is not suitable for the analysis of complex community richness. It is clear that there are large differences between $H^{\prime}$ index (Fig.3) and actual individual and group richness characteristics in the study (Figs.1 and 2). In the present study, we used DG index for the diversity analysis of soil fauna. DG index was introduced in 1990, and amended in 1997 by Liao et al. (1997). The advantages of the DG index lie in the better feasibility in the diversity analysis among various communities. However, the disadvantage of DG index is that it can not demonstrate the relationships within each group. Soil fauna are generally polyphagous, thus the relationships among different groups may be relatively less important compared with the effects of external factors. 


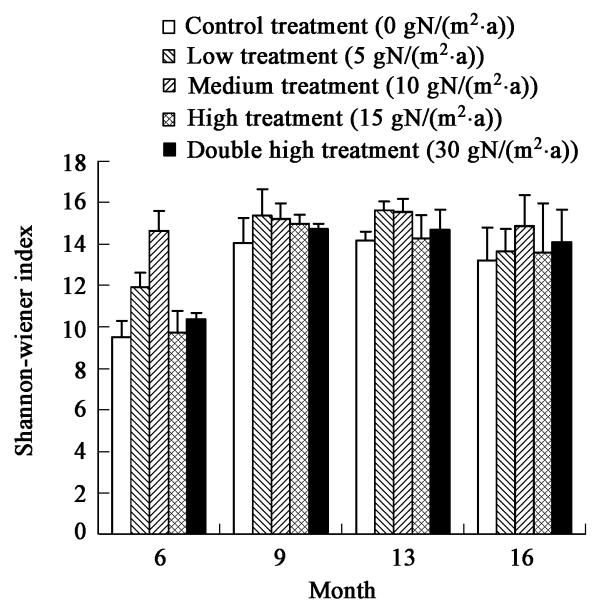

$$
\begin{aligned}
& \text { - Soil layer I }(0-5 \mathrm{~cm})--- \text { Soil layer II }(5-10 \mathrm{~cm}) \\
& \text {-.- Soil layer III }(10-15 \mathrm{~cm})
\end{aligned}
$$

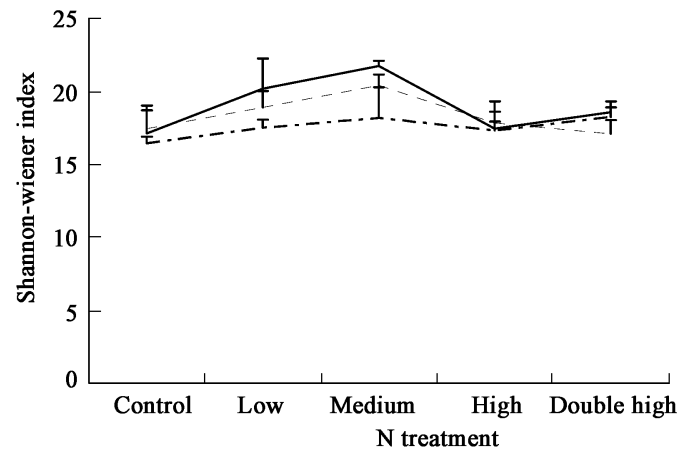

Fig. 3 Shannon-Wiener indexes of soil fauna under the effects of nitrogen, sampling date and soil depth. X-axis of left figure represents months after the experiment beginning.

In the present study, DG index clearly illustrated the characteristics of soil fauna individuals and group richness (Figs.1 and 2), and it was a useful index to indicate the diversity of complex community of soil fauna.

\section{Acknowledgements}

The authors are grateful to Dr. Melanie Lenart for her comments and work on the manuscript, and to Mrs. Yue D. Yang and Mr. Ding S. Mo for their work in the laboratory, also thank the anonymous reviewers for their valuable comments and suggestions on the manuscript.

\section{References}

Abrahamsen G, Thompson W N, 1979. A long term study of the enchytraeid (Oligochaeta) fauna of a mixed coniferous forest and the effects of urea fertilization[J]. Oikos, 32: 318327.

Bartnicki J, Alcamo J, 1989. Calculating nitrogen deposition in Europe[J]. Water Air Soil Pollute, 47: 101-123.

Bergkvist B, Folkeson L, 1992. Soil acidification and element fluxes of a Fagus sylvatica forest as influenced by simulated nitrogen deposition[J]. Water Air Sois Pollut, 65: 111-133.

Boxman A W, Blanck K, Brandrud T, 1998. Vegetation and soil biota response to experimentally-changed nitrogen inputs in coniferous forest ecosystems of the NITREX project[J]. Forest Ecology and Management, 101: 65-79.

Chou R L, Wu Q, 1997. Study on the sensitivity to terriecosystem to acid precipitation[J]. Advances in Environmental Science, 4: 8-22.

Fenn M E, Poth M A, Aber J D, 1998. Nitrogen excess in North American ecosystems: predisposing factors, ecosystem responses, and management strategies[J]. Ecological Applications, 3: 706-733.

Foster N W, Hazlett P W, Mcolson J A, 1989. Long leaching from a sugar maple forest in response to acidic deposition and nitrification[J]. Water Air Soil Pollut, 48: 251-261.

Fu B Q, Chen W, Dong X H et al., 2002. The composition and structure of the four soil macrofaunas in Songshan Mountain in Beijing[J]. Acta Ecologica Sinica, 22: 215223.

Galloway J N, Cowling E B, 2002. Reactive nitrogen and the world: 200 years of change[J]. Ambio, 31: 64-71.
Gonzalez G, Seastedt T R, 2001. Soil fauna and plant litter decomposition in tropical and subalpine forests[J]. Ecology, 82: 955-964.

Holland E A, Dentener F J, Braswell B H et al., 1999. Contemporary and pre-industrial global reactive nitrogen budgets[J]. Biogeochemistry, 46: 7-43.

Hou A M, Peng S L, Zhou G Y, 2002. Tree-ring chemical changes and possible impacts of acid precipitation in Dinghushan, South China[J]. Acta Ecologica Sinica, 22: 1552-1559.

Huang L X, Sheng S H, 1996. A study of the effects of soil animals on soil nutrients in non-tillage ecosystem[J]. Rural Eco-Environment, 12: 8-10.

Institute of Soil Science, CAS, 1985. Methods of soil microbial[M]. Beijing: Science Press. 81-82.

Kros J, De Vries W, Janssen P H M, 1993. The uncertainty in forecasting trends of forest soil acidification[J]. Water Air Soil Pollut, 66: 29-58.

Kuperman R G. 1996. Relationships between soil properties and community structure of soil macroinvertebrates in oak-hichory forests along an acidic deposition gradient[J]. Applied Soil Ecology, 4: 125-137.

Li D J, Mo J M, Fang Y T, 2003. Impact of nitrogen deposition on forest plants[J]. Acta Ecologica Sinica, 23: 1891-1900.

Liao C H, Li J X, Huang H T, 1997. Soil animal community diversity in the forest of the southern subtropical region[J]. Acta Ecol Sin, 17: 549-555.

Lindberg N, Persson T, 2004. Effects of long-term nutrient fertilisation and irrigation on the microarthropod community in a boreal Norway spruce stand[J]. Forest Ecology and Management, 88: 125-135.

Liu G S, Jiang N H, Zhang L D et al., 1996. Soil physical and chemical analysis and description of soil profiles[M]. Beijing: Standards Press of China. 121-265.

Magill A H, Aber J D, Berntson G M, 2000. Long-term nitrogen additions and nitrogen saturation in two temperate forests[J]. Ecosystems, 3: 238-253.

Nkem J N, Lobry de Bruyn L A, Hulugalle N R, 2002. Changes in invertebrate populations over the growing cycle of an $\mathrm{N}$ fertilised and unfertilised wheat crop in rotation with cotton in a grey Vertosol[J]. Applied Soil Ecology, 20: 69-74.

Pamela M, Kathleen A, Sharon J H, 2002. The globalization of nitrogen deposition: consequences for terrestrial ecosystems[J]. Ambio, 31: 113-119.

Rodgers D, 1997. Soil collembolan (Insecta: Collembola) assemblage structure in relation to understorey plant species and 
soil moisture on a eucalypt woodland site[J]. Memoirs of the Museum of Victoria, 56: 287-293.

Sarathchandraa S U, Ghani A, Yeates G W et al., 2001. Effect of nitrogen and phosphate fertilisers on microbial and nematode diversity in pasture soils[J]. Soil Biology \& Biochemistry, 33: 953-964.

Su Y C, Zhang C B, Gou Y B, 1995. Relationship between seasonal quantitative variation of soil animals in wheat field and environmental factors in northeast heavy frigid region of China[J]. Chinese Journal of Ecology, 14: 10-14.

Su Y C, Gou Y B, Zhang Z H, 2001. Ecology characters of soil faunas and microorganisms in the north-east heavy frigid region of China[J]. Acta Ecologica Sinica, 21: 1613-1619.

Sulkava P, Huhta V, Laakso J, 1996. Impact of soil faunal structure on decomposition and $\mathrm{N}$-mineralization in relation to temperature and soil moisture in forest soil[J]. Pedobiologia, 40: 505-513.

Townsend A R, Braswell B H, Holland E A, 1996. Spatial and temporal patterns in terrestrial carbon storage due to deposition of fossil fuel nitrogen[J]. Ecological Applications, 6: 804-814.

Verhoef H A, Dorel F G, Zoomer H R, 1989. Effects of nitrogen deposition on animal-mediated nitrogen mobilization in coniferous litter[J]. Biol Fertil Soils, 8: 255-259.

Watmough S A, Hutchinson T C, Sager E P S, 1999. The impact of simulated acid rain on soil leachate and xylem chemistry in a Jack pine (Pinus banksiana Lamb) stand in northern Ontario, Canada[J]. Water Air Soil Pollut, 111: 89-108.
Whalen J K, Parmelee R W, Edwards C A, 1998. Population dynamics of earthworm communities in corn agroecosystems receiving organic or inorganic fertilizer amendments[J]. Bio Fertil Soils, 27: 400-407.

Xia H P, Yu Q F, Zhang D Q, 1997. The soil acidity and nutrient contents, and their characteristics of seasonal dynamic changes under 3 different forests of Dinghushan Nature Reserve[J]. Acta Ecol Sin, 17: 645-653.

Xiao H L, 2001. Effects of atmospheric nitrogen deposition of forest soil acidification[J]. For Sin, 37: 111-116.

Xu G L, Mo J M, Zhou G Y, 2003. Relationship of soil fauna with $\mathrm{N}$ cycling and its response to $\mathrm{N}$ deposition[J]. Acta Ecol Sin, 23: 2453-2463.

Yin W Y, 1998. Pictorical keys to soil animals of China[M]. Beijing: Science Press.

Zhang X P, 1995. On the relation of soil animal to environmental quality[J]. Natural Sciences Journal of Harbin Normal University, 11: 95-99.

Zhang C B, 2002. The seasonal dynamics of soil microorganism, mini-animal and their biochemical activities in the wheat field of northeastern China[J]. Plant Nutrition and Fertilizer Science, 8: 372-376.

Zhou G Y, Yan J H, 2001. The characteristics of regional precipitation and the impact of its nutrient concentration on the development of forest ecosystem in Dinghushan[J]. Acta Ecol Sin, 21: 2002-2012.

Zhen L Y, Gui H, 1999. Insect classification[M]. Nanjing: Nanjing Normal University Press. 